\title{
Terrestrial snails that are parasitologically important of Turkey
}

\author{
Mehmet Zeki YILDIRIM ${ }^{1}$, Mustafa Emre GÜRLEK², Fatma Selcan KUŞ²
}

${ }^{1}$ Mehmet Akif Ersoy University, Bucak School of Health, Burdur/TURKEY

${ }^{2}$ Mehmet Akif Ersoy University, Burdur Vocational School of Health Services, Burdur/TURKEY

\author{
Key Words: \\ snail \\ intermediate host \\ parasitology

\section{Anahtar Kelimeler: \\ salyangoz \\ ara konak \\ parazitoloji} \\ Received: 28.09.2018 \\ Accepted: 10.12.2018 \\ Published Online: 31.12.2018 \\ Article Code: 465502 \\ Correspondence: \\ MZ. YILDIRIM \\ (mzekiyildirim@gmail.com)
}

\section{ORCİD:}

MZ. YILDIRIM: 0000-0003-0282-2232 ME.GÜRLEK: 0000-0002-9249-1331 FS. KUS: 0000-0002-3244-0831

\begin{abstract}
Up to now, 12 snail species have been determinted as a intermediate host Helicella candicans (Ziegler, 1841), Xeropicta krynickii (Krynicki, 1833), Trochoidea pyramidata (Draparnaud,1805), Monacha cartusiana (O. F. Müller, 1774), Cochlicella acuta (O. F. Müller, 1774), Helicella itala (Linnaeus, 1758), Cernuella virgata (Da Costa, 1778), Helicopsis protea (O. F. Müller, 1774), Helicella obvia (Menke, 1828), Helix aspersa O. F. Müller, 1774, Helix lucorum Linneaus, 1758, Chondrus tournefortianus (A. Ferussac, 1821) in Turkey. Unfortunately, classification mistakes are made by the fact that the host, intermediate host and parasites are from separate groups of animals. Particularly in relation to intermediate hosts, these are: Helicella candicans is synonim of Xerolenta obvia. Probably the researchers have noted snail belong to this species from old and invalid literatures. Its same for the Helicella obvia, its synonim of the Xerolenta obvia. Helicopsis krynickii, Its synonim of the Xeropicta krynickii; Monacha carthusiana is also synonim of Monacha claustralis. Also Helicella obvia is synonim of Xerolenta obvia. Helicella itala and Helicopsis protea never has been found in Turkey. Probably reason of only morphological description. Because this species distributing in western Europe (from Italia and Austria till whole Britania).
\end{abstract}

\section{Türkiye'nin parazitolojik öneme sahip olan kara salyangozları}

$\ddot{O} z$

Türkiye de şimdiye kadar yapılan çalışmalarda 12 salyangoz türü ara konak olarak belirlenmiştir (Helicella candicans (Ziegler, 1841), Xeropicta krynickii (Krynicki, 1833), Trochoidea pyramidata (Draparnaud,1805), Monacha cartusiana (O. F. Müller, 1774), Cocblicella acuta (O. F. Müller, 1774), Helicella itala (Linnaeus, 1758), Cernuella virgata (Da Costa, 1778), Helicopsis protea (O. F. Müller, 1774), Helicella obvia (Menke, 1828), Helix aspersa O. F. Müller, 1774, Helix lucorum Linneaus, 1758, Chondrus tournefortianus (A. Ferussac, 1821). Maalesef, konakçı, ara konakçı ve parazitlerin ayrı hayvan gruplarından olması nedeniyle ciddi sınıflandırma hataları yapılmaktadır. Özellikle ara konaklarla ilgili olarak, bunlar: Helicella candicans, Xerolenta obvia'nın sinonimidir. Muhtemelen araştırmacılar, ara konak salyangozların tanımlamalarını eski ve geçersiz literatürden yararlanarak yapmışlardır. Helicella obvia, Xerolenta obvia'nın sinonimi; Helicopsis krynickii, Xeropicta krynickir nin sinonimi; Monacha carthusiana da Monacha claustralis'in sinonimidir. Ayrıca Helicella obvia, Xerolenta obvia'nın sinonimidir. Helicella itala ve Helicopsis protea türleri Türkiye'de yayılış göstermemektedir. Bu iki tür İtalya ve Avusturya'dan Biritanya dahil tüm Batı Avrupa'da yayılış göstermektedir. Muhtemelen araştırıcılar sadece morfolojik tanımlama yapmışlardır.

\section{INTRODUCTION}

The Mollusca, one of the largest phyla of living creatures, includes gastropod species able to colonise every humid corner of the planet. Given their adaptability to a range of diverse ecosystems, molluscs have been long known to serve as ideal hosts for a number of parasites, including nematodes and trematodes. Indeed, gastropods act as intermediate hosts for a range of helminth parasites of medical and veterinary concern, including more than 18,000 digenean trematodes and about roundworm species ranked into the superfamily Metastrongyloidea (1).

There are several studies on this large group of parasites and snails but there is a few studies to determine the relationship on the intermediate host. Till now, it has been determined that 245 terrestrial snail species have been determined in malakofauna of Turkey $(2,3)$. While to be host potentially of these species are known, there are few studies on which parasite uses the snail as an intermediate host.

In a study around the Keban Region of Elazig, 20 snails (Helix lucorum) samples were examined interm of endohelmintes and Paragonimus sp. (Trematoda; Digenea) and Protostrogylus sp. (Nematoda; Metastrongyloidea) were determined in the intestine of snails. The abundance, prevalance and mean intensity for Paragonimus sp. were found $20 \%, 5 \%$ and 4 parasites per snail respectively. These values for Protostrongylus sp. were also found $30 \%, 5 \%$ and 6 parasites per snail respectively (4).

Unlu et al (2017) have found H. lucorum snails as a intermediate hosts for Dicrocoelium trematodes with a prevalence of $22 \%(5)$.

Gürelli and Göçmen (2007) have found H. aspersa as an 
intermediate host in the life cycle of Dicrocoeliidae and it had a prevalence of $0.97 \%(6)$.

Gürelli et al (2014) have studied the prevalence of Dicrocoeliid larval stages in Helix lucorum Linneus 1758 in the vicinity of Kastamonu and founded prevalence as 27.6\% (7).

Soykan and Öge (2012) have studied on the prevalence of liver trematodes in equines in different cities of Turkey and found percents $5.1 \%$ with liver flukes. And also Infection rates were found to be Fasciola hepatica 2.6\%, in donkeys (8).

Gürelli and Alay (2016) have first record of the natural infection of Chondrus tournefortianus by Dicrocoeliidae larval stages in Kastamonu. They have found prevalence of the infection in Kastamonu, was $2.27 \%$, with the highest value occurring in October. Also they have given a list about comparision of the prevalence in different land snail species infected with Dicrocoeliidae larval stages. These species and prevalence in Turkey: Helicella candicans 4.0, Helicopsis krynickii 2.6, Trochoidea pyramiadata 0.2, Monacha carthusiana 2.8, Cochlicella acuta 0.4, Helicella itala 5.68, Cernuella virgata 1.0, Helicopsis protea 0.8, Helicella obvia 26.8, Helix aspersa 0.97, Helix lucorum 27.6, Chondrus tournefortianus (9).

Kartal, K., et al.(2015) have studied on the prevalence of liver trematodes in Helix lucorum Linnaeus, 1758, and found as 4,9\% in vicinity Afyonkarahisar (10).

Balkaya et al (2009) have found Dicrocoelium dendriticum infection around $31.1 \%$ ratio in Erzurum vicinity (11). Cengiz et al (2010) have found a human infection with Dicrocoelium dendriticum in Turkey (12). All these studies show that there is a widespread trematod and nematode infection in our country. It is clear evidence that the same type of infection was found in the high-rate Dicrocelias in Erzurum and also in a human. However, there are very few studies of how these parasites develop at the intermediate host level. For this reason, it is necessary to understand the life cycle of common parasites and the intermediate hosts. Because the information will be the most important step in protecting against such diseases.

The aim of this study was to determine the distribution of the snail intermediate host which have taken place in Turkey as well. To know their distribution will be a source of knowledge for those working with such parasites.

\section{MATERIAL and METHODS}

The snail samples given in the study have collected from all regions of Turkey by the first author since 1994. All materials are kept in the personal collections in Burdur Mehmet Akif Ersoy University Faculty of Science and Arts and the Museum. These species: Xerolenta obvia (Menke, 1828) from Istranca Mountain (June, 1994); Xeropicta krynickii (Krynicki, 1833) from Silivri, Istanbul (July, 2016) and Tekirdağ (July, 2016); Trochoidea pyramidata (Draparnaud, 1805); from Antalya (September, 2014) and Tekirdağ (July, 2016); Monacha (Monacha) claustralis (Mousson, 1859) from Akdağ Isparta (June, 2014), Karakent village (June, 2014); Cocblicella acuta (Müller, 1774) from Nazilli (June, 2008), Çandir Isparta (June, 2014); Cryptopmhalus aspesus (O.F. Müller, 1774) from Hevsel Gardens, Diyarbakır (April 1994) and Bodrum, Fethiye (June, 2008); Helix (Helix) lucorum (Linnaneus, 1758) from Keçiborlu Kap- lanlı Village (August 1998), Gümüşgün Burdur (2001), Dereçine village Afyon (2001); Chondrus tournefortianus (A. Ferussac, 1821) from Bayburt Castle (June, 1996), Çoruh Valey, Artvin (June, 1996).

Samples were included in the collection collected by standard methods and techniques. Fechter \& Falkner 1990, Gittenberger 2000, Hausdorf 2000, Schütt 2010 were used to differentiate species $(2,3,13,14)$.

\section{RESULTS}

Up to now, 12 snail species have been determinted as a intermediate host (Helicella candicans, Helicopsis krynickii, Trochoidea pyramiadata, Monacha carthusiana, Cochlicella acuta, Helicella itala, Cernuella virgata, Helicopsis protea, Helicella obvia, Helix aspersa, Helix lucorum, Chondrus tournefortianus) in Turkey.

The general characteristics and distributions of these species are briefly given;

\section{Helicella candicans}

The name of species has used by Schileyko in 1978. After this articles, Fechter \& Falkner and Schutt have changed as Xerolenta obvia (2).

\section{Xerolenta obvia (Menke, 1828)}

1828 Helix obvia, MENKE, Synopsis Metthodica Molluscorum. (1): 13. NOM.

1978 Helicella candicans,- Schileyko, Helicoidea: 224-225, F.252-254

1989 Xerolenta obvi, -Fechter \& Falkner, Weichtiere, 208,209.

2010 Xerolenta obvia, - Schutt, Turkish Land Snails, p: 456

The information given under these two species names, as seen in the synonym list, is probably misleading because of the morphologically-based description. Because the shell morphology of these taxons given as synonyms is very similar. Probably the researchers have noted snail belong to this species. As typically the background color is whitish with not itterrupted dark brown spiral bands. It is known from only the west parts of Trakya region. Members of this species prefer dry and open habitats and calcerous grassland. So its possible to pass of the trematodes larveas easly in these habitats. Materials: Dry and open grasslands around Istranca Mountain (June, 1994).

\section{Helicopsis krynickii}

Its synonim of the Xeropicta krynickii (2).

4. Xeropicta krynickii (Krynicki, 1833)

1960 Helicopsis (Xeropicta) krynickii, - Zilch in Wenz, Hdp,Pal.6(2,4): 672

1989 Xeropicta krynickii, -Fechter \& Falkner, Weichtiere, 206,207 .

2010 Xeropicta krynickii- Schutt, Turkish Land Snails, p: 452

As typically this species has an irregularly developed pattern of interrupted more or less broad spiral bands. This species distributed in Marmara and Black Sea regions in Turkey and also Black Sea Basin conturies, Bulgaria and Greece (2,3). They 
live at open habitats on dampish and cultivated areas, herbages, in forests. Materials: from Silivri, Istanbul (July, 2016); from Tekirdağ (July, 2016).

\section{Trochoidea pyramidata (Draparnaud, 1805)}

Shell typically conic and with 7 regularly increasing convex whorls. They live on dry vegetation, usually in coastal vicinity distibuted in West, Meditterenean and Trakya part of Turkey. Materials: from Antalya (September, 2014), from Tekirdağ (July 2016).

\section{Monacha carthusiana}

Since long time Monacha samples collected from West Anatolia has accapted as $M$. cartusia reason of big concologic similarity. This species distributing in Western Europe and America (Naturalist). Hausdorf (2000) examined the genital anatomy of these specimens and identified them as Monacha claustralis $(2,3,14,15)$.

\section{Monacha (Monacha) claustralis (Mousson, 1859)}

1967 Monacha (Monacha) carthusiana,-Hudec, Casopis Narodn, Mus., 136(2):89, F. 5.

1996 Monacha (Monacha) carthusiana, -Schütt, Landschnecken Turkey:382 (part)

2000 Monacha (Monacha) claustralis, - Haudorf, Arch. Mollusknkunde, 128(1/2): 80-82.

2010 Monacha (Monacha) claustralis, - Schütt, Turkish Land Snails, $424 \mathrm{p}$.

This species widespread in Western Turkey. Materials: from Akdağ Isparta (June, 2014), Karakent village (June 2014).

\section{Cocblicella acuta (O.F. Müller, 1774)}

Shell turrated, 8-10 slighly convex. They have seen in Marmara, Aegean, Mediterrenean and Blacksea regions. Generally in coastal areas from the Atlantic islands to Caspian coastlands (3). They live on dry places, coastal grassland, abundant shrubs or low trees. Materials: from Nazilli (June, 2008), Çandır, Isparta (June, 2014).

\section{Helicella itala (Linnaeus, 1758)}

This species lives in western Europe (in Scotland, northern England, Wales, Cornwall and northern Ireland, but not Shetlands), in the north to southern Scandinavia, in the east to central Germany and Austria (western Niederösterreich) to France and northern Spain (15). It never has been found in Turkey. Probably the examples gathered because of similarity to other species are given this name.

\section{Helicopsis protea (Haas, 1933)}

It never has been found in Turkey. Probably the examples gathered because of similarity to other species are given this name. There is a controversy over the existence and classification of this taxon. For the first time, Haas gave it as a subspecies and Gittenberger gave it on the synonym list of the Xeropicta ledereri mavromoustakisi taxon in his work in Cyprus and mentioned the distributing in Cyprus (13).

\section{Helicella obvia}

This taxon is listed on synonym list of Xerolenta obvia (Menke, 1828) previously.

\section{Helix aspersa}

Its synonim of Cryptophalus aspesus (O.F. Müller, 1774).

13. Cryptopmbalus aspesus (O.F. Müller, 1774)

1774 Helix aspersa O.F. Müller, Verm. Terr.fluv. hişt., 2: 59

1989 Cryptopmbalus aspesus Fechter \& Falkner, Weichtiere, 244, F. 1, 245

2010 Cryptopmbalus aspesus Schütt, Turkish Land Snails, 501.

In Turkey nearly everwhere in natural and cultivated habitats. In the vicinity Mediterranean, Aegean and Black Sea costs. Its and edible snail also there alots of farms in EU. Recently it has started farming activities in Turkey. Materials: from Hevsel Gardens, Diyarbakır (April, 1994), from Bodrum, Fethiye (June, 2008).

\section{Helix lucorum (Linnaeus, 1758)}

1758 Helix lucorum Linnaeus, Syst. Nat., 10: 773

This species distribution all over the Turkey. Its known Turkish snail and gathering for export. Materials: from Keçiborlu Kaplanlı Village (August, 1998), Gümüşgün Burdur (2001), Dereçine village Afyon (2001).

\section{Chondrus tournefortianus (A. Ferussac, 1821)}

1998 Chondrus tournefortianus, - Schileyko, Ruthenica, Supp. 2: 224

1998 Chondrus tournefortianus, - Schütt, Turkish Land Snails, 128.

Shell sinistral coiled spindle shaped. It has distributed Marmara, Middle and North Anadolu Regions. Materials: from Bayburt Castle (June, 1996), Çoruh Valey, Artvin (June, 1996).

\section{DISCUSSION}

Turkey is a country with high biological diversity. There is also a rich variety of snails. Animal husbandry is common and takes place in the form of small family farms. Exterior grazing is also common. All of this is necessary for the parasite loop. Therefore, we are expecting a parasitic fauna rich in both qualitative and quantitative in our country. This is undoubtedly a negative influence for livestock. Therefore, one of the first steps in the struggle against parasites is to know the parasites life cycle well.

In Turkey has not been adequately studied in this regard. However, in the last few years, good work has begun to take place. Parasites, hosts and intermediate hosts are composed of very diverse animal groups. It is therefore a necessity for these different groups of animals to be well known. As a matter of fact, few studies have made mistakes on intermediate hosts. These are: Helicella candicans (8) is synonim of Xerolenta obvia. Probably the researchers have noted snail belong to this species from old and invalid literatures. Its same for the Helicella obvia, its synonim of the Xerolenta obvia. Helicopsis krynickii, Its synonim of the Xeropicta krynickii; Monacha carthusiana is also synonim of Monacha claustralis $(2,3)$. Helicella itala, never has 
been found in Turkey. Probably reason of only morphological description. Because this species distributing in western Europe (15). Helicopsis protea never has been found in Turkey. Probably reason of only morphological description (13). Helicella obvia is synonim of Xerolenta obvia $(2,3)$.

\section{REFERENCES}

1. Giannelli A, Cantacessi C, Colella V, Dantas-Torres F, Otranto D, Gastropod-Borne Helminths: A Look at the SnailParasite Interplay. Trends in Parasitology. Volume 32, Issue 3, p255-264, 2016.

2. Fechter R, Falkner G. Weichtiere.1-111 Meeresmollusken, 112-286 Binnenmollusken, München, Mosaic Verlag. 1990.

3. Schütt H. Turkish Land Snails. Verlag Natur \& Wissenschaft Solingen, 2010.

4. Sağlam N, Gökhan, H. B. Elazı̆̆, Keban Yöresinde Yașayan Salyangoz (Helix lucorum Linnaeus, 1758)'da Endohelmintlerin Araştırlması. E.Ü. Su Ürünleri Dergisi Cilt/Volume 23, Ek/ Suppl. (1/2): 287-289. 2006.

5. Unlu AH, Bilgic HS, Eren H, Karagenc T. Prevalence of Larval-Stage Dicrocoeliidae (Digenea) trematodes in Helix lucorum (Mollusca: Pulmonata) in Van Province. Turkiye Parazitoloji Dergisi 41: 204-7, 2017.

6. Gürelli G, Göçmen B. Natural Infection of Helix aspersa (Mollusca: Pulmonata) by Dicrocoeliidae (Digenea) Larval Stages in Izmir, Turkey. Türkiye Parazitoloji Dergisi, 31 (2): 150153, 2007.

7. Gürelli G, Alay M, Koymalı S. The prevalence of Dicrocoeliid (Trematoda: Digenea)larval stages in Helix lucorum Linneus 1758 (Mollusca: Pulmonata) in the vicinity of Kastamonu. Turkiye Parazitol Derg. 38(1): 37-40. 2014.

8. Soykan E, Öge H. have The Prevalence of Liver Trematodes in Equines in Different Cities of Turkey. Turkiye Parazitol Dergisi; 36: 152-5, 2012.

9. Gürelli G, Alay M. First record of the natural infection of Chondrus tournefortianus (Mollusca: Pulmonata) by Dicrocoeliidae (Digenea) larval stages in Kastamonu, Turkey North-Western Journal of Zoology 12 (1): 188-191, 2016.

10. Kartal K, Köse M, Eser M. Afyonkarahisar Yöresi'nde Birinci Ara Konak Helix lucorum Linnaeus, 1758 (Mollusca: Pulmonata)'da Küçük Karaciğer Kelebeği Dicrocoelium dendriticum'un Larval Safhalarının Yaygınlı̆̆. Kocatepe Veteriner Dergisi, Cilt 8, Say1 1, 2015.

11. Balkaya İ, Asena K., Küçükkalem ÖF. Dicrocoelium dendriticum ile Enfekte Koyun Karaciğerleri Üzerinde Parazitolojik ve Patolojik İncelemeler Atatürk Üniversitesi Vet. Bil. Derg., 4 (3): 169-175, 2009.

12. Cengiz ZT, Yılmaz H, Dülger AC, Çiçek M. Human infection with Dicrocoelium dendriticum in Turkey. Ann Saudi Med. 2010 Mar-Apr; 30(2): 159-161.

13. Gittenberger E. On Cyprian Helicellinae (Mollusca: Gastropoda Pulmonata: Helicidae), making a new start. Zool. Mededelingen, 65/7, Leiden, 2000.
14. Hausdorf, B. The genus Monacha in Turkey (Gastropoda: Pulmonata: Hygromiidae). Arc. Molluskunde, 128(1/2): Frankfurt, 2000.

15. http://www.iucnredlist.org/details/156313/0, 2018. 